\title{
Educating Youth Against Tobacco Advertising: A Media Literacy Approach for Reducing Indonesia's Replacement Smokers
}

\author{
Santi Indra Astuti \\ Faculty of Communication Science, Bandung Islamic University, No.1 Tamansari Street, Bandung \\ E-mail: santi@unisba.ac.id
}

\begin{abstract}
Neglecting the plea to sign Framework Convention on Tobacco Control (FCTC), Indonesia's has became a country in emergency situation facing the rise of smokers among its people. According to recent data extracted from Global Tobacco Atlas (2015), about 66\% Indonesian males aged no less than 15 years old are active smokers. It means 2 among 3 Indonesian males are smokers. The number of young smokers arose significantly. Smokers among 15-19 years old has increased $17 \%$ each year, meanwhile, baby smokers among 5-9 years old has multiplied $400 \%$. These figures implied the rise of health risk among Indonesians. Every year, the tobacco industry tries to recruit young people to replace those current smokers who are dying or quitting. This youth being targeted by tobacco industry is called 'replacement smokers', and is lured to start smoking through the work of advertising and creative marketing strategy. A study carried out by Health Ministry of Indonesia showed that 70\% youth were started to smoke after heavily exposed by cigarette advertising. In order to break tobacco advertising spell, a brand jamming strategy based on media literacy approach was conducted toward junior high school pupils. By educating them about advertising behind the scene and challenging them to be creatively produce a 'mocking'version of popular tobacco ads, students now are capable enough of deconstructing the real message behind tobacco ads.
\end{abstract}

Keywords: advertising, tobacco, brand jamming, replacement smokers, media literacy

\begin{abstract}
Abstrak: Mengabaikan permohonan untuk menandatangani Framework Convention on Tobacco Control (FCTC), Indonesia telah menjadi negara dalam situasi darurat yang menghadapi perokok di antara masyarakatnya. Menurut data terbaru yang diambil dari Global Tobacco Atlas (2015), sekitar 66\% pria Indonesia yang berusia tidak kurang dari 15 tahun adalah perokok aktif. Artinya, 2 di antara 3 pria Indonesia adalah perokok. Jumlah perokok muda muncul secara signifikan. Perokok di antara 15-19 tahun telah meningkat 17\% setiap tahun, sementara itu, perokok bayi berusia antara 5-9 tahun telah melipatgandakan 400\%. Angka-angka ini menyiratkan meningkatnya risiko kesehatan di kalangan masyarakat Indonesia. Industri tembakau mencoba setiap tahun untuk merekrut kaum muda untuk mengganti perokok yang sedang sekarat atau berhenti merokok. Pemuda yang menjadi sasaran industri tembakau ini disebut 'perokok pengganti', dan terpikat untuk mulai merokok melalui kerja periklanan dan strategi pemasaran kreatif. Sebuah studi yang dilakukan oleh Kementerian Kesehatan RI menunjukkan bahwa 70\% remaja mulai merokok setelah sangat terpapar iklan rokok. Untuk memecahkan mantra iklan tembakau, strategi kemacetan merek berdasarkan pendekatan literasi media dilakukan terhadap siswa sekolah menengah pertama. Dengan mendidik mereka tentang periklanan-balik-adegan dan menantang mereka untuk secara kreatif menghasilkan 'mengejek'versi iklan tembakau populer, siswa sekarang cukup mampu untuk mendekonstruksi pesan sebenarnya di balik iklan tembakau.
\end{abstract}

Kata kunci: iklan, tembakau, gangguan merk, perokok pengganti, literasi media 


\section{INTRODUCTION}

In a country whose risk of young smokers is soaring high, educating the youth to avoid smoking habit is quite challenging. This is the case of Indonesia, which had been labeled globally as 'baby smoker's country'. The label came after a 2 year old boy named Aldi Rizal was found at Sumatera in 2010. Back on the awful year, Aldi was able to smoke 40 cigarettes a day. He became the joke of the neighborhood for imitating adult's behavior, but on the other hand, his case sparked rage and anger among health campaigner activists both in the country and at international level toward cigarette companies operated freely in Indonesia. Aldi was successfully rehabilitated until now. And Indonesia government has applied plain packages regulation ever since. Unfortunately, the problem was far from over.

As cited from a monitoring report in five big cities of Indonesia (2015), which is involved 360 schools, tobacco sellers and tobacco advertising has systematically targeted young people as tobacco industry's replacement smokers to fulfill empty places being left by adult smokers who quitted for many reasons. Such conclusion resulted from several findings, i.e.: (1) Around 30 cigarette brands were found around shops surrounding schools.(2) Despite the fact that school as education institution had been established as no smoking area, the shops surrounding the school have been selling cigarettes freely. (3) Cigarette outdoor advertisings, in the form of billboard, posters, leaflets, stickers and banners had been found in more than $40 \%$ schools being observed. (4) Cigarette promotion had been found in more than $54 \%$ schools being observed. They were promoting discounted price, selling cigarette economy pack (lipstick packed, contained two cigarettes), promoting contest, sponsoring events, and so on.
(5) $88 \%$ of schools being observed became cigarette's point of sales - both voluntarily and involuntarily (STAR Report, 2015).

A series of interview held by researchers revealed that an area covered a hundred meters around schools was established as 'a golden area' for tobacco selling and promotion. Cigarette marketers and distributors competed against each other to occupy that so called golden area. A shopkeeper admitted that a brand has offered him no less than 3 million IDR/year to set up special display for cigarette packs, painted the shop with colors symbolizes the brand, and built a signage displaying the name of the shop along with the cigarette brand, of course. Outside of the golden area around schools, the shops seemed dull and less attractive, the cigarette's marketers were not really paid special attention to them. But, those kind of places was still attract smokers. The more hidden the place, the better for young smokers - and their teachers, tooin order to avoid themselves to smoke publicly.

Given this situation, where school environment were unable to control tobacco sellers in luring and seducing schoolchildren to smoke, several approach must be applied, ranging from the restrictive one to the more persuasive approach. Restrictive approach was usually based on taxation control and regulation measure. Meanwhile, a more persuasive approach implies preventive actions rather than the curative one. Among persuasive strategy being applies to anti-smoking campaign, media literacy approach is one of them. This article will review the application of media literacy approach against tobacco industries notion in reproducing replacement smokers among youth in Bandung, West Java Province of Indonesia. But first of all, we will discuss why is media literacy approach became the option to solve the problem. 


\section{Cigarette advertising, brand activation and brand jamming}

First of all, let me reiterate the important position of replacement smokers for tobacco industries. Replacement smokers is a term defined by tobacco industries for smokers wannabe replacing 'adult/senior smokers' that quit from smoking habit for several reasons. As Myron Johnston stated on market research report on young smokers titled "Young Smokers Prevalence, Trends, Implications, and Related Demographic Trends" (1981).

“...today's teenager is tomorrow's potential regular customer and the overwhelming majority of smokers first begin to smoke while in their teens. ... The smoking patterns of teen-agers are particularly important to Philip Morris. . . the share index is highest in the youngest group for all Marlboro and Virginia Slims packings. At least a part of the success of Marlboro Red during its most rapid growth period was because it became the brand of choice among teenagers who then stuck with it as they grew older" (Feighery, 2013).

To be recorded, Myron E. Johnston is a Philip Morris researcher who doing extensive research in 1970-1980s to map the trends of consumer's attitude toward the brand. One of its findings was the rise of trend among teens to smoke which was related with the success of aggressive tobacco marketing among youths. The research had been approved by Carolyn Levy and Harry Daniel, and cited by tobacco control activists everywhere as a proof of an evil plan built carefully by a large tobacco company.

Obviously, it is in the hands of replacement smokers that the future fate of tobacco industries lies. Being potent future consumers, replacement smokers became the key of survival for cigarette manufacturer. Without replacement smokers, the existence of cigarette manufacturer will only be a history. Therefore, it is understandable if tobacco industries focuses its marketing operation to produce replacement smokers.

To reach the notion, cigarette advertising became powerfulweapon used by tobacco industry to recruit replacement smokers. Through cigarette advertising, smoking habit was constructed as 'cool'. Several studies revealed that cigarette advertising played important role in influencing teenagers' perception toward smoking as normal habit, even something 'cool' that define their identity. The theme of such advertising is also something that really close with youth worlds and expectations, such as adventure, elite lifestyle, courage, success, music, hanging out, joy, bravery, reckless but 'cool' (Mutmainnah, Hendriyani and Armando, 2012). Other studies has also spotted certain 'youngsters' values appeared in cigarette advertising, i.e. freedom, urban lifestyle, modern, dynamic, enthusiast, glamour, trendy - these keywords were appeared in a cigarette brand display on several marts. It must be admitted too that cigarette advertisings are visually attractive in deliver their 'good' values. Amongst other things, most cigarette advertising characters are young people, or characterizes young attitudes and attributes. As has been cited by an advertising expert, Hermawan Kartajaya, "cigarette has successfully associated its brand with everything that attracts young people" (Warta Kampus, 2013:13).

It is also important to recite University of Hamka (Uhamka)'s research in cooperation with National Commission on Children Protection (Komisi Nasional Perlindungan Anak) in Jakarta, Bogor, Tangerang and Bekasi (2007). The survey concluded that $46 \%$ teenagers start smoking due to cigarette advertising, 50\% teenagers felt that their identity represented by people who 
appeared in the cigarette advertising. 29\% youth smokers lit their cigarettes after being exposed by cigarette advertising (Lentera Anak Indonesia, 2013). In other places, similar research were conducted. The results were no significantly different.

In 2003, cigarette advertising and promotion in Indonesia was valued at \$ 520 million. Ten years later, the amount were multiplied and reach as high as $\$$ 912 million (www.youtube.com/watch? $\left.\mathrm{v}=\mathrm{rxFij} 5 \mathrm{z} \_\mathrm{se} 4\right)$. Apart from restrictions exercised by government to Indonesia's tobacco industry, cigarette advertisings are still difficult to resist. Its influence is also proved to be effectively maintaining smoking habit, including in educating early smokers. Tobacco advertising used many tactics to influence and approach potential target. One of such tactics is brand activation strategy, i.e, a marketing effort to integrate all communication facilities by employing creative platform intended to activate consumers (Alberts, 2011).

'Activating' consumers means stimulating (1) passion/concerns; (2) trial; (3) loyality/satisfaction. The methods are varied, and advertising is just one of its tool. Branding is much more than advertising. The postmodern individual demands that brands live up to their promises in every interaction whether it is through products and services, employees, identity or communication (Morel, Preisler, \& Nystrom, 2002). This basic model (picture 1) is delivered by Stephen van Belleghem in his book "The Conversation Manager" (2011). According to him, the core of brand activation is tweets, conversation, talks whose messages led to certain brand or issue being published/being promoted. Brand activation will function and reach its optimum in the situation "... where the RIGHT people talk about the brand as CONVERSATION topic for the RIGHT reasons."

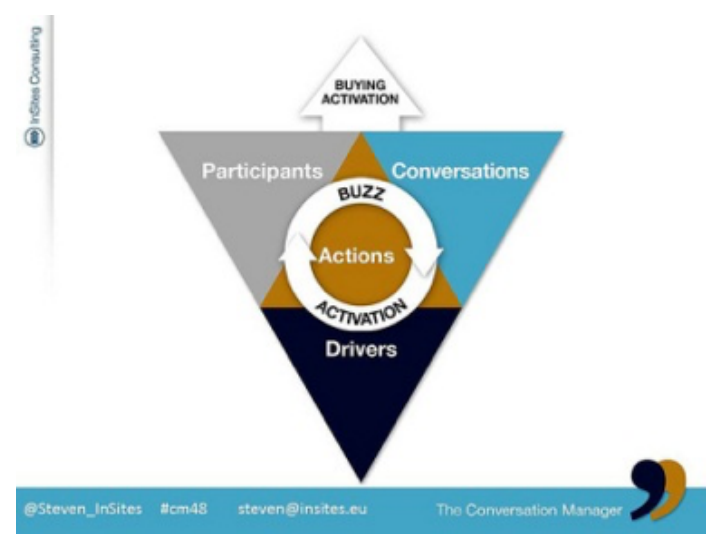

FIGURE 1. Basic Model of Brand Activation

Van Belleghem's model of brand activation depicted triangle of participants which represented audience/ consumers, conversation between participants, and drivers or things that triggering the conversation. Buzz is issues or messages referring to the brand (or cases) able enough to manage in such a way to 'activate' or inducing stimuli to the audience or target.

Brand activation targeted audience minds, which unconsciously associated a product with certain values. This strategy is best applied for cigarette advertising who was subjected to government restriction in visualizing cigarette and smoking action. In order to manipulate such restrictions, cigarette advertising delivered beautiful narration and image which associate smoking (and its brand) with positive values such as friendship, solidarity, luxury, lush and exclusive lifestyle, and respect (honoring the elders, cultural norms, etc.)

To anticipate brand activation strategy, antismoking activists now uses brand jamming strategy - a strategy designed to distracted brand (and its promotion activities as well) promoted through brand activation. Brand jamming stemmed from cultural jamming activities, namely " $\ldots$ an organized, social activist effort that aims to counter the 
bombardment of consumption-oriented messages in the mass media (Handelman \& Kozinets, 2004 in Carducci, 2006).

There are few methods to execute culture jamming, according to the target 'being jammed or being distracted.' Brand jamming is aimed at distracting a brand, meanwhile, issue jamming focuses on disturbing issue or certain discourse. Tweet jamming means a social media discussion which deliberately held for promoting or distracting issues/ discourses. Whatever the themes are, the principle of brand jamming is executing anti-campaign activities, or anti-ads aimed to attack brand activation strategy through mock ad, flash mob, social media campaign, festivals/event, etc. (Bloomberg in Feighery, 2013). For anti-smoking campaign purposes, antismoking activists will choose best options to execute brand jamming strategy by reflecting on main factors which causes its target to become replacement smokers. Social situations and media being accessed most on their life are considered very important in order to perpetrate the strategy. In order to implement that, media literacy approach kicks in!

\section{METHODS}

\section{Media literacy: educating youth against the agenda of tobacco industry}

As we reflected to the whole situation faced by Indonesia concerning the rise of replacement smokers among its young generation, it is obvious enough that cigarette advertisings played dominant role in educating the youth and preparing them to be replacement smokers. A content analysis toward hidden messages delivered by the ads has found several 'positive values' to be associated to tobacco products, especially cigarettes. Being exposed with such positive values, any passive targets cannot comprehend the real situation. They are involuntarily obeying the hidden instructions provided by the advertising message. Smoking begins and become a regular habit. Chain of smokers is maintained over and over again.

So, based on the case, breaking the chain of smokers need an act of intervention. The intervention must be aimed to the core of problems: save the target from tobacco advertising attack. To do that, one shall be awaken up and be conscious of the hidden message behind advertising. In other words, audience's consciousness toward advertising and promotion messages is the key against tobacco advertising influence among its target. Of course, it's not the consciousness only which we talked about. A capability to evaluate mass media messages in many forms, including advertising, is critical for audience. Especially for those being targeted as consumers, in this case, as replacement smokers.

But, what is media literacy?

Media literacy started from the idea of injecting a kind of immunity among audience in such a way so that the audience could resist the negative effect of mass media. This is a common concept derived from effects studies that blamed mass media as the cause of changing norms among society. But, exploration of the concept on different level poses us with ontological challenge: acknowledging the negative effects of mass media cannot erasing the positive effects of mass media itself, especially with the advance of communication technologies and the evolving audience nowadays. So, the idea of media literacy as fortress built to resist mass media negative effects became building 'people's ability to access and process of information from any form of transmission' (Potter, 2014:15). It shifted the focus of media literacy from the risks of harmful media effects to an appreciation of communication media and adapting it to our changing world. In order to accommodate the changing 
perspective on how we perceive mass media effects, the formal definition of media literacy become like this: "Media Literacy is a set of perspectives that we actively use to expose ourselves to the mass media to interpret the meaning of the message we encounter" (Potter, 2014: $25)$. With that concept, media literacy needs strong knowledge structures in five areas: media effects, media content, media industries, the real world, and the self (Potter, 2014: 19).

Meanwhile, the goal of media literacy toward the audience is building seven skills of media literacy consisted of: (1) analysis -breaking down a message into meaningful elements; (2) evaluation -judging the value of an element; the judgment is made by comparing a message element to some standard; (3) grouping -determining which elements are alike in some way; determining how a group of elements are different from other groups of elements; (4) induction -inferring a pattern across a small set of elements, then generalizing the pattern to all elements in the set; (5) Deduction -using general principles to explain particulars; (6) synthesis assembling elements into a new structure; and (7) abstracting -creating a brief, clear and accurate description capturing the essence of a message in a smaller number of words than the message itself (Potter, 2014:20).

\section{FINDING AND DISCUSSION}

Back to research problems focused on heavily exposed tobacco advertising among teens, which led us to making use of media literacy approach as brand jamming strategy against the spell of tobacco advertising, let us remember that while actively maintain its activities among society, media were packed with certain agendas - its own agendas. Political agenda of mass media usually implemented in the form of news and editorials by exposing facts, issues, or occurrence in such a way intended to set up public opinion (or influencing it as well) favorably or infavorably toward certain issues, public figures, political options, and so on (Andika, 2012). News agenda has led public/audience toward something that considered as 'important' by media, or ignoring others (considered unimportant) as well (Faucheux, 2003: 43). Narration and fictional content delivered through films, stories, and dramas shaped our symbolic perception toward the real world. Who can deny the effects of telenovelas and soap operas among its fans and viewers? Advertising, as one of media texts, also had its own agenda driven by its notion. Simply speaking, advertising agenda is drawing potential consumers to choose the product, consume it, buy it, and making repeat order. Or, delivering and creating specific perception in the minds of potent consumers toward the product being promoted/advertised which paved the way to deliver marketing operation (Bagozzi, Gurhan-Canli \& Priester, 2012:18).

According to Armando, a well noted communication scholars-cummember of national broadcasting committee, "media literacy provide us with any capability needed to manage content and communication, in order to protect us and our family against the risk of extensive media use" (2014). This kind of capability was also needed by audience being exposed by massive advertising operation. Media literacy toward advertising will help audience to differentiate needs and wants. They will be able to reveal that behind attractive advertising messages, lies strong notion to indulge audience with consumerism. A critical capability of audience in evaluating mass media message and deconstructing visual images appear on the ads would protect audience from advertising operations which draw them 
to consume regardless the fact that they don't really need the product being advertised. Moreover, through media literacy, the audience could understand more about the reason why they are being targeted as potent consumers for certain products.

Based on those 'logic', media literacy approach is the right option to resist tobacco industries' brand activation strategy. Through media literacy capabilities, teenagers targeted by tobacco industries would be equipped with capacity that enabled them to differentiate facts and figures, to capture the trap of content visualization and hidden message on different layers of the message, to grab the essence of message, and exposing the real values (or ideology) being offered to the consumers as passive audience.

In order to implement the approach, series of media literacy workshop were created in the form of capacity building which targeted junior high school pupils as its participants. Three schools in Bandung were being contacted and agreed to participate. SMP Darul Hikam, SMP Negeri 7 and SMP Negeri 2 were chosen due to the fact that massive TAPS or tobacco advertising, promotion and sponsorship was found heavily around their location. One school, SMP Negeri 40, was resign from the program for 'internal reasons' which we found, later, associated with male teacher's smoking habit. Each program (for each school) was designed for 25-30 students. We worked with the school administration to choose student envoy represented their own classes or their organization (Student Union, Scout, even Hobbyist Organization). After three days of capacity building sessions, the participants were given opportunities to create their own program to 'fight back' the tobacco advertising attacks.

The 'curriculum' being set up for this capacity building was mainly drawn from media literacy and visual literacy indicators. Visual literacy is a specific form of media literacy whose goals were equipping students with capability to differentiate images and facts, and extracting the real messages behind pictures, illustrations, and other form of visuals (Messaris in Kubey, 2001: 142). The reason why visual literacy approach was employed is based on the facts that visual images became the form of message mainly delivered to its target through the work of advertising. So, it is important to comprehend the formal convention of visual media in order to decode representation of objects being delivered through advertising.

Dealing with advertising needs specific type of skills and knowledge structure. Potter outlined a detailed types of skills and knowledge structure needed to deal with advertising message in media-literate manner, as below:

TABLE 1. Knowledge and Skills of Media Literacy Approach Focusing on Advertising

\begin{tabular}{lcll}
\hline Area of Skills & Code & \multicolumn{1}{c}{ Skills } & \multicolumn{1}{c}{ Knowledge } \\
\hline Cognitive & A1 & $\begin{array}{l}\text { Ability to analyze an advertise- } \\
\text { ment to identify key elements of } \\
\text { persuasion }\end{array}$ & $\begin{array}{l}\text { Knowledge on topic from many } \\
\text { sources (media and real world) }\end{array}$ \\
\cline { 2 - 3 } & A2 & $\begin{array}{l}\text { Ability to compare and contrast } \\
\text { key elements of persuasion in } \\
\text { the ad with facts in your real } \\
\text { world knowledge structure }\end{array}$ \\
\cline { 2 - 3 } & A3 & $\begin{array}{l}\text { Ability to evaluate veracity of } \\
\text { claims in the ad }\end{array}$ \\
\hline
\end{tabular}




\begin{tabular}{|c|c|c|c|}
\hline \multirow[t]{2}{*}{ Emotional } & B1 & $\begin{array}{l}\text { Ability to analyze the feelings } \\
\text { of people in the ad }\end{array}$ & \\
\hline & $\mathrm{B} 2$ & $\begin{array}{l}\text { Ability to put one's self into the } \\
\text { position of different people in } \\
\text { the ad }\end{array}$ & \\
\hline \multirow[t]{2}{*}{ Aesthetic } & $\mathrm{C} 1$ & $\begin{array}{l}\text { Ability to analyze the craft and } \\
\text { artistic elements of the ad }\end{array}$ & $\begin{array}{l}\text { Knowledge of writing, graph- } \\
\text { ics, photography, and so on. }\end{array}$ \\
\hline & $\mathrm{C} 2$ & $\begin{array}{l}\text { Ability to compare and contrast } \\
\text { the artistry used to craft this } \\
\text { ad with that used to craft other } \\
\text { types of ads }\end{array}$ & $\begin{array}{l}\text { Knowledge of successful and } \\
\text { unsuccessful ads and the ele- } \\
\text { ments that contributed to those } \\
\text { qualities }\end{array}$ \\
\hline \multirow[t]{2}{*}{ Moral } & D1 & $\begin{array}{l}\text { Ability to analyze the moral ele- } \\
\text { ments of an ad }\end{array}$ & $\begin{array}{l}\text { Knowledge of criticism of ad- } \\
\text { vertising and knowledge of how } \\
\text { ads can manipulate our attitudes } \\
\text { and behaviors. }\end{array}$ \\
\hline & D2 & $\begin{array}{l}\text { Ability to evaluate the ethical } \\
\text { responsibilities of advertisers }\end{array}$ & Highly developed moral code \\
\hline
\end{tabular}

(Potter, 2014)

Based on type of skills and knowledge structure for decoding cigarette advertisements, and adjust it with the goal of enlightening audience concerning tobacco facts and figures which in turn, aiming to reduce replacement smokers, subjects being delivered on student's capacity building sessions were consisted of: (1) An explanation about advertising logic in mass media (A1, A2); (2) A short lecture on tobacco industries and why it matter most (A1, A2); (3) Forms of advertising often found in mass media (B1, A2); (4) A discussion over advertising target, and the reason beyond (D1); (5) A discussion aimed to produce best way to promote product through advertising $(\mathrm{C} 1, \mathrm{C} 2) ;(6)$ Critical evaluation toward advertisingdelivered through game (D1); (7) Critical evaluation toward cigarette advertising delivered through game (B1, B2, D1, D2); (8) Identification of values as shown by tobacco/cigarette advertising (A3, D2); (9) Contestation of values as appear on tobacco advertisement, juxtaposed it with facts and research result concerning cigarette and smoking habit (A1, A2, A3, D1); (10) Creating map for identifying cigarette advertising and its placement around school or neighborhood, or other No Smoking Area (Kawasan Tanpa Rokok-KTR) (A2); and (11) Creating a mock advertising in the form of meme and posters symbolizes a fight back action against tobacco industries which unethically targeted young people to smoke.

Subject 1-9 were delivered in class seminars. Meanwhile, subjects 10 required students to walk around their own school to spot TAPS and assessing their neighborhood. Subject 11 is in progress. The students, clustered in a group of 5-7 person, has reached the creative phase. Their goals are delivering a fight back message to the society and tobacco industry by creating a 'mock' advertising. Comparing pre-test and posttest results, the difference was significant. Students' awareness toward situation around their school environment was built. Understanding that the school environment was contaminated by TAPS, the students then joined a campaign 'selling no tobacco/cigarettes for students' and negotiated with shop owners around schools to replace tobacco brand banner 
with their own banner containing antismoking messages. They even invited other parties to support their action, for example, district administration, local police, city watchmen, etc.

Of course, effort to reduce the rising amount of replacement smokers through this intervention process is far from over. A monitoring process is still going on, and another strategy to advocate students was needed. To conclude that this approach has effectively reducing replacement smokers' amount is also considered too premature-more evidence was needed to reach validity. But, as the first step of creating a valid model for intervention purposes, the media literacy approach concentrating on building skills and knowledge structure focusing on cigarette advertisements has proven to be effective for youths who participated in the program. The media literacy approach focusing on (cigarette) advertising itself reflecting a brand jamming strategy perpetuated to disturb or to intervene brand activation strategy of tobacco advertising. An application of the approach on larger scale was needed to test the model, and refashioning method of deliverance is a must.

\section{CONCLUSION}

In a country where smoking habit is perceived 'normal', contesting the tobacco industry campaign to create new consumers a.k.a replacement smokers was actually a desperately silent endeavour. Tobacco industry has long reigned in Indonesia, and successfully marked themselves as part of native culture. Supporting by seemingly unlimited resources and funds for propaganda, promotion and advertising, tobacco industry created a smart marketing strategy based on brand activation which could encompasses government restrictions and regulations for tobacco-based-products. If brand activation became the keyword for such strategy, then a brand jamming strategy must be offered to resist tobacco industry's effort in producing more and more replacement smokers.

Reflecting on that situation, educating youth not to smoke is not effective anymore if it is conducted in conventional manner. By applying principles of media literacy to decode cigarette advertising, a new model was created to implant consciousness among audience toward the real message of cigarette advertising. Moreover, by setting up a capacity building combined with advocacy efforts, students were able to transform themselves from passive audience to critical youths. This transformation enabled them not only to resist the effect of advertising, but also to actively involve as agents of anti-smoking campaign.

\section{REFERENCES}

Alberts, Paul G. 2011. "Defining Brand Activation." A Brandbase Review. Retrieved on December 3 $3^{\text {rd }}, 2014$ from http://www.brandactivation.nl.

Andika, Dicky. 2012. "Brand dan Citra Politik Pemerintah dalam Perspektif Pertarungan Berita di Media Massa". Proceeding of NCCB, Malang, January $24^{\text {th }}, 2012$.

Bagozzi, Richard P., Zeynep Gurhan-Canli \& Joseph R. Priester. 2002. "The Social Psychology of Consumer Behavior". Buckingham: Open University Press.

Belleghem, Stephen Van. 2011. Research: $T V$ advertising and brand activation increase purchase intention. Retrieved on May $20^{\text {th }}, 2015$ from http://www. stevenvanbelleghem.com/blog/ research-tv-advertising-and-brandactivation-increase-the-purchaseintention.

Carducci, Vince. 2006. "Culture Jamming: A Sociological Perspective". Journal of Consumer Culture. Retrieved on December $3^{\text {rd }}, 2014$ from http://joc. 
sagepub.com.

Dugis, Noveina Silviyani. 2012. "Meaningful Marketing Communication Strategy in Higher-Education Sebagai Usaha Peningkatan Brand Perguruan Tinggi Swasta (Studi Kasus Higher Education Branding di Universitas Katholik Widya Mandala Surabaya). Proceeding of NCCB, Malang, January $24^{\text {th }} 2012$.

Facheux, Ronald A. 2003. "Winning Elections: Political Campaign Management, Strategy \& Tactics". New York: M. Evans \& Company.

Feighery, Ellen. 2013. “Assessing Compliance with Tobacco Advertising, Promotion, and Sponsorship(TAPS) Bans: A 'Howto' Guide for Conducting Compliance Studies of Point of Sales Advertising \& Product Display, Outdoor Advertising \& Product Packaging". Baltimore: Institute for Global Tobacco Control, John Hopkins Bloomberg School of Public Health.

Mesaris, Paul. "Visual Literacy: A Cross Cultural Perspective" in Kubey, Robert (ed.). 2001. "Media Literacy in the Information Age: Current Perspective. Information \& Behavior Volume 6". New Brunswick, US: Transaction Publisher.

Morel, Paul, Peter Preisler \& Anders Nystrom. 2002. "Brand Activation". Starsky Insight, February 2002. Retrieved on December $3^{\text {rd }}$, 2014 from http://www. metro-as.no.

Mutmainnah, Nina., Armando, Ade \& Hendriyani. 2012. "Membendung Pengaruh Iklan Rokok di Kalangan Remaja". Community Program Proposal. Jakarta: FISIP UI.

Potter, W. James. 2014. "Media Literacy" (7 $7^{\text {th }}$ edition). LA, USA: Sage Publication.

STAR Report: "Serangan Iklan di Sekitar Sekolah: Kajian Monitoring di 5 Kota Besar Indonesia (2015)." Jakarta: Coalition of Fikom Unisba, Smoke Free Agents, Lentera Anak Indonesia and Yayasan Pengembangan Media dan Anak. 